\title{
Identification of Social and Economic Expectations: Contextual Reasons for the Transformation Process of Industry 4.0 into the Industry 5.0 Concept
}

\author{
Sebastian Saniuk $^{1, *(\mathbb{D})}$, Sandra Grabowska ${ }^{2, *(\mathbb{D})}$ and Martin Straka ${ }^{3}$ (D) \\ 1 Department of Engineering Management and Logistic Systems, University of Zielona Gora, \\ 65-417 Zielona Gora, Poland \\ 2 Department of Production Engineering, Silesian University of Technology, 40-019 Katowice, Poland \\ 3 Institute of Logistics and Transport, Technical University of Kosice, 04200 Kosice, Slovakia; \\ martin.straka@tuke.sk \\ * Correspondence: s.saniuk@wez.uz.zgora.pl (S.S.); sandra.grabowska@polsl.pl (S.G.)
}

Citation: Saniuk, S.; Grabowska, S.; Straka, M. Identification of Social and Economic Expectations: Contextual Reasons for the Transformation Process of Industry 4.0 into the Industry 5.0 Concept. Sustainability 2022, 14, 1391. https://doi.org/ $10.3390 /$ su14031391

Academic Editor: Piera Centobelli

Received: 29 December 2021

Accepted: 24 January 2022

Published: 26 January 2022

Publisher's Note: MDPI stays neutral with regard to jurisdictional claims in published maps and institutional affiliations.

Copyright: () 2022 by the authors Licensee MDPI, Basel, Switzerland. This article is an open access article distributed under the terms and conditions of the Creative Commons Attribution (CC BY) license (https:// creativecommons.org/licenses/by/ $4.0 /)$.

\begin{abstract}
The dynamic development of the fourth industrial revolution, focused on the implementation of Industry 4.0 technologies, sparked fears of governments and society regarding the dehumanization of the industry in the future. Currently, there is a need to consider sustainable development and the crucial role of man in the assumptions of industry's future development. Concerns about the implementation of the fourth industrial revolution's technology became the basis for building the assumptions of Industry 5.0. The article aims to identify the social and economic expectations of the development of the fourth industrial revolution in the context of the development of the sustainability, humanization, and resilience of Industry 4.0. The article presents the results of research obtained based on a critical analysis of the literature and surveys conducted among representatives of Polish society. As a result of the research, key social expectations as to the directions of development of the Industry 4.0 concept were identified. Recommendations for industry development focused on three areas of development-human-centric, sustainable, and resilient-were established. The presented research results will allow the development of an investment strategy and a government policy to support the development of industry based on the human-centric digitization of the economy.
\end{abstract}

Keywords: fourth industrial revolution; Industry 4.0; Industry 5.0; social expectations; resilient; sustainability

\section{Introduction}

The fourth industrial revolution ushered in the creation of cyber-physical systems (CPS) by integrating information and communication technology (ICT) and operational technologies in enterprises and supply chains. Initially, the idea was to completely eliminate humans from the manufacturing process and replace them with autonomous machines and devices supported by artificial intelligence solutions. Nowadays, there is a belief that technologies used in the Industry 4.0 concept cannot impose their choices on people; they should, rather, be supported. The first mentions of the role of operators in Industry 4.0 appeared in the publications of Romero et al. [1]. The development of the industrialization process from Industry 4.0 (I4.0) to Industry 5.0 (I5.0) is dictated mainly by the need to reveal the human role in cyber-physical systems (CPS). Currently, an approach is being developed in the design of modern industry that promotes the symbiosis of humans with new technologies. The new approach to creating factories of the future is called the human cyber-physical system (HCPS). The humanization of the built technological environment for Industry 4.0 was one of the first factors in the evolution of Industry 4.0 towards Industry 5.0. In addition to the human factor, authors have noted research gaps in sustainability, responsibility, safety, and other issues in the Industry 4.0 concept [2]. 
Many publications address the sustainability aspect of Industry 4.0 [3-6]. Luthra and Mangla [4] presented a topic on supply chain sustainability and de Sousa Jabbour et al. [5] on Industry 4.0 and the circular economy. The barriers of Industry 4.0 in social and economic terms are presented in Saniuk et al. [7]. Other authors (scientists, researchers) have also participated in discussing the social and environmental problems (gaps) of Industry 4.0 [8-27]. Ranghino [28] undertook a discussion on environmental risks. Bonilla et al. [29] wrote about the impact of new digital technologies on the environment and sustainability, creating optimistic and pessimistic scenarios. A similar topic was analyzed by Pagoropoulos et al. [6], analyzing the negative impact of digital technologies on a circular economy. Interesting considerations on sustainable consumption in the development of industries and economies were undertaken by Terlau and Hirsch [30]. The main purpose of the deliberations in many publications is to seek consensus among different communities (scientific, political, business) on the need to better integrate social and environmental priorities in the industrialization of the economy.

According to the European Commission (EC), the power of Industry 5.0 is a societal goal that goes beyond job creation and development to become a resilient provider of prosperity by ensuring that manufacturing respects the limits of our planet and puts the well-being of industrial workers at the heart of the manufacturing process [31].

Based on a systematic literature review, a research gap was identified in identifying the social and economic expectations of the digitalization of businesses and communities as well as the concepts of Industry 4.0. The considered research problem focuses on answering the question: What are the current trends in the social and economic expectations of society in the context of Industry 4.0 implementation. In particular, the concerns and opportunities that society sees in the universal digitization of the economy have been identified. The article aims to identify the social and economic expectations of the development of the fourth industrial revolution in the context of the sustainability, humanization, and resilience of Industry 4.0. The authors of this publication wish to contribute to the discussion on the new direction of industrial development, defined according to the time chronology of industrialization-Industry 5.0.

\section{Review of the Subject Literature}

\subsection{Towards Industry 4.0 and Industry 5.0}

Industry 4.0 represents the integration of intelligent resources (machines and equipment) and information technologies, making production processes more efficient. Industry 4.0 is a new approach and new form of working, creating new roles for people in industry [9-15,32-43]. I4.0 is a subset of the fourth industrial revolution. Customers and business partners cooperate within business processes and create new value by using high-quality services. Thanks to the intelligent monitoring of systems in real-time, companies can control and optimize their activities and make decisions efficiently [16-20,44-47].

Industry 4.0 is a revolution in manufacturing control methodology, including dynamic machine changeovers initiated by information carried in workpieces. Communication in I4.0 at the factory level and in extended networks requires broadband communication, including the transmission of smart sensors, resources, and equipment in real-time. New solutions implemented in factories result in changing management paradigms and building new business models based on maintaining the balance between the development of autonomous (intelligent) technology and remote communication systems and the quality of life and recognized values in different societies [21-24]. The changes that are taking place in industry 4.0 include a wide range of innovations at the level of plants and factories belonging to various industries and services as well as the functioning of entire societies [25,26,48-52]. Industry 4.0 is essentially a trend towards automation and data sharing in the technologies and processes of production that include CPS, Internet of Things (IoT), cloud computing, cognitive computing, and artificial intelligence [53,54]. 
Hermann, Pentek, and Otto [9] defined Industry 4.0 as CPSs, the Internet of Things, the Internet as a service, and the smart factory. They used this definition to propose six principles supporting Industry 4.0 solution implementation. These are:

- Interoperability-the ability of an enterprise's systems and employees to cooperate within data exchange and coordination activities.

- Virtualization-involves supervising the physical flow processes using one or more virtual resources with the simultaneous participation of physical resources.

- Decentralization-refers to moving to multiple systems instead of a central system to reduce risk and provide operational flexibility.

- Real-time virtualization capability—the ability to process all system data in real-time to facilitate decision-making.

- Service orientation and modularity—using Big Data technology and predictive analytics to support and understand customer needs.

- Modularity - the ability of companies to adapt to changing industry demands and needs flexibly.

Regarding topics in the Industry 4.0 area, there is a lot of focus on sustainability aspects - consumer, business models, and the economy. Stock and Selinger [19] defined Industry 4.0 as the next stage in the creation of sustainable industrial value that must focus on sustainable development and production. By providing precise information about the production process [52], resources, and energy consumption, the producer can optimize the production system across the network value [53]. The new technological solutions promoted by Industry 4.0 should increase the production efficiency and environmental performance of products throughout their life cycle. This implies an increased need for smart technologies of production. In a sustainable market, customers (consumers) should focus on "environmentally friendly" products that are renewable, shared, and characterized by an ability to recycle [27].

The fourth industrial (technological) revolution has expanded the boundaries of what companies can provide as value to customers. In today's highly competitive manufacturing environment, companies face the challenge of dealing with large data sets, the need to make quick decisions, and the flexibility of manufacturing processes [54]. The modern nature of manufacturing is shaped by a paradigm shift from mass production to unit and batch production, oriented to satisfying customer needs and providing customized products. The range of customer expectations from products is extensive and diverse [8,54-57].

The considerations conducted so far in the literature still emphasize the technological changes that should be introduced in the production companies of Industry 4.0. However, due to its effects in all areas of the economy, the industrial revolution should be understood more broadly. Noteworthy are the changes in creating a new strategy focused on meeting social, economic, and environmental needs in the scope of all links in the value chain and customer orientation $[10-12,35,58]$.

The discussion on the effective implementation and use of Industry 4.0 technology is ongoing. At the same time, a new trend of the fifth industrial revolution is emerging, going beyond the production of goods and services for profit. Industry 5.0 brings a new look to the industry and requires everyone to change their minds and behaviors [59].

Industry 5.0 is an industry that focuses on the return of humans to the production system. In this revolution, man and machine find ways to work together to improve the quality and efficiency of production. The interaction of human and artificial intelligence is paramount in Industry 5.0. The fifth industrial revolution is also more beneficial for the environment as companies develop systems that use renewable energy and eliminate waste [60-62].

According to the EC, the strength of Industry 5.0 is the social goal, beyond jobs and economic growth, of becoming a resilient provider of well-being by making the manufacturing industry respect the planet's boundaries and putting the well-being of the industrial worker at the center of the production process. The main ideas of the Industry 5.0 concept were considered by the participants of a meeting of research and technology 
organizations organized by the European Commission (EC) on 2-9 July 2020 [31]. At that time, the basic principles of the Industry 5.0 concept were developed, and key directions of change were proposed to make the industry more sustainable and human-centered [60].

The premise of Industry 5.0 focuses on greater human involvement in cyber-physical systems and creating interaction in the human-machine system [61]. The interaction involves connecting humans with smart devices and the cyber-physical system through smart mobile devices [62]. Today, robots appear to be replacing humans due to advances in artificial intelligence development and the potential for brain-machine interface development [63-65]. This means, in the future, a strong combination of robots with a human brain and the use of them as collaborators and executors of commands rather than competitors [66]. The idea of Industry 5.0 will therefore focus on developing more advanced human-machine interfaces using artificial intelligence (AI) algorithms. This represents an opportunity to harness the capabilities of human brains to increase the efficiency of the automation and robotization of systems [67]. This means breaking with the view of losing control of the cyber-physical world, dominated by thinking robots, which was feared in the Industry 4.0 era [68]. The transformation of the Industry 4.0 concept to Industry 5.0 represents a combination of the advantages of a cyber-physical system of intelligent machines and common sense thinking, which can mean a focus on productivity and sustainability [68-72].

In human-machine integration, it is also essential to develop competence and knowledge in new technologies and the trend of talent management. The future is based on investment in employee retraining and the lifelong learning process. According to Forbes, about $34 \%$ of HR leaders invest in developing strategies to prepare for new technologies [73]. This implies a need to focus on talent development and talent management for employees to improve the productivity of systems and better orient to the needs of the economy and society $[74,75]$.

It is expected that Industry 5.0 will create many new jobs in human-machine interaction (HMI) and human computational factors (HCFs). Some of the most critical areas in which jobs will be created include intelligent systems, artificial intelligence and robotics, machine programming, machine learning, maintenance, and training [76]. The goal of Industry 5.0 is a higher standard of living and creativity through high-quality custom-made products that lead to sustainable production and consumption. A favorable factor for the development of the Industry 5.0 concept is the growing environmental awareness of society. This means interest in green products, the sharing economy, and interest in developing a circular economy [77].

Industry 5.0 emphasizes the importance of technology for industrial development. Still, at the same time, it promotes social goals in the workplace, e.g., it emphasizes workplace safety with next-generation technologies or human-machine relationships and external purposes, i.e., social and environmental responsibility [78]. Industry 5.0 does not deny the necessity of digitizing societies, economies, and industries but instead extends it with social and environmental aspects [79].

Digitalization in Industry 5.0 is a broad philosophy that organizes enterprise and supply chains processes. Within this philosophy, digitalization and elements of artificial intelligence penetrate people's everyday life. Hence, scientists believe that Industry 5.0 is creating the idea of "Society 5.0" [80-82]. Society 5.0 is limited to industry and solves social problems by integrating physical and virtual space. Society 5.0 is a society in which advanced technologies are actively used in people's lives, industry, health care, and other spheres, not for the sake of progress, but for the benefit and quality of life [83,84].

\subsection{Society 5.0 in the Era of the Fourth Industrial Revolution}

The fourth industrial revolution, Industry 4.0, and Industry 5.0 are technological changes and social and industrial changes caused by the digital transformation of industry. The fourth industrial revolution can be defined as the age in which modern technical solutions and technologies shape the industrial environment and influence the economy and 
society, intensifying sustainable development $[32,35,40]$. The fourth industrial revolution's megatrends are Economic 4.0, smart factories, Society 5.0, sustainable consumption, and sustainable production [85].

The modern world is characterized by a highly uncertain and volatile environment. This applies to many spheres of life: technology, economy, work, culture, and values. Castells [86] aptly calls modernity "constant change". Bauman [87], on the other hand, refers to it as "liquid modernity" in which everything changes, nothing is stable or predictable, and every organization and every person must be flexible and constantly adapt to new conditions [88]. Modern technologies and the pace of the commercialization of research results make the changes occurring in production organizations extremely dynamic. However, it is not the new technologies or the rate of change that pose the most significant challenges in today's market environment. There is a technological dominance of changes in production, services, education, science, and administration, which is the basis of intelligent automation, robotization, logistics, and communication. It is the material that binds together individuals' professional, private, and social lives and even entire communities. Joint enterprise research, marketing, or after-sales service is the path to joint sustainable production [33-36]. Economies of scale are the engine of globalization, and Industry 4.0 and 5.0 are its next stage of development.

The idea of Industry 4.0 determines economic change leading to Economy 4.0 [37-39,89], which encompasses a fully digital value chain from suppliers through to intermediaries and brokers to the end customer (the recipient of the product/service), regardless of who that customer is: a business, consumer, building owner, retail store owner, employee, citizen, passenger, or patient $[43,90]$.

Economy 4.0 is, on the one hand, Industry 4.0 and 5.0 with smart factories. On the other hand, there is the extension of smart concepts to many sectors, such as smart grids, smart mobility and transportation, smart buildings, smart healthcare, and smart farming. The scope of Economy 4.0 can be divided as follows [91]:

- 4.0 technologies applied to the smart factory;

- 4.0 technologies applied to inter-factory collaboration (smart or not);

- Manufactured smart things deployed in smart end-user environments;

- Digital services provided to the users of smart environments.

Keidanren [92] believes that creativity and imagination should undoubtedly be the key to shaping the future. In 2016, Keidanren published a declaration, "Towards the realization of a new economy and society-Reforming the economy and society", which established Society 5.0 as a new vision for the further responsible development of society. He defined Society 5.0 as a human-centered society that balances economic progress with social problem-solving through a system that integrates cyberspace and physical space. Artificial intelligence, Big Data, and the Internet of Things are just some of the areas of research and development that are becoming part of everyday life [40]. Everyone's life is becoming saturated with digital data and information technologies through which we develop and share ideas, generating new business ideas. With the advent of smartphones, there are new ways of shopping, new ways of working, and the like, and our picture of the world and everyone's daily life is changing a lot [41,42]. Digital technology enables the next industrial revolution, thereby changing the previous production-centric society into an intelligent society whose attribute is information [93-95].

The Japanese government made an analysis and, based on this, developed the "Fifth Science and Technology Base Plan," which was adopted in January 2016. The plan envisions a transition from Industry 4.0 to Society 5.0, in which all aspects of society, including industrial work, are shaped by the latest techniques and technologies. Japan has been faced with the need to develop a new model for how society will function. It experiences problems with energy shortages and imports, limited natural resources, and an aging population. The policymakers' main idea is to use artificial intelligence (AI) to solve long-term social and economic problems. In doing so, the Japanese government has developed the Japan Revitalization Strategy 2015 [96] and the Japan Growth Strategy 2017 [97], outlining how it 
will work to promote economic growth in key areas of the economy. New economic growth will be supported by the development of artificial intelligence, the continuous robotization of society, and the automation of industry with ubiquitous super-fast communication.

In the information society-also called Society 4.0-knowledge and information are insufficiently shared. Members of cross-sector teams do not adopt the same values, limiting the potential outcomes of collaboration in society [98,99]. In contrast, Society 5.0 suggests using intelligent technologies to connect people by sharing knowledge and information to create new social and business chains [100-102]. Society 5.0 envisions the use of modern technology and information solutions to free humans from exhaustive routine work and improve available information. Society 5.0 is defined as a human-centered society in which economic progress, containing solutions to social issues, is balanced by a system that offers the high integration of digital and real space. Thus, we are talking about a society characterized by a higher level of integration, the interpenetration of both realities-digital and real-facilitating the embedding of cyberspace in the real world. Such a society can also be called a super-intelligent society or a creative society [100-103].

Society 5.0 aims to create a world in which essential goods and services are delivered to everyone anytime, anywhere, regardless of region, age, gender, language, or other constraints. It aims to simultaneously achieve gross domestic product (GDP) and prosperity and overcome social challenges, thereby contributing to the community's well-being. Society 5.0 is expected to affect daily life but focuses mainly on economic and social aspects (Table 1) [92].

Table 1. Areas of economic and social change in Society 5.0.

\begin{tabular}{|c|c|}
\hline Area & Activity \\
\hline Cities and Regions & $\begin{array}{l}\text { Better data sharing on energy, transportation, water, waste, } \\
\text { people movement. } \\
\text { Decentralization of communities in suburbs and rural areas; } \\
\text { respect for diversity. }\end{array}$ \\
\hline Energy & $\begin{array}{l}\text { Development of affordable, sustainable energy. } \\
\text { Development of systems that respond to local conditions. } \\
\text { Information sharing between organizations. }\end{array}$ \\
\hline Prevention of disasters & Use of digital technologies. \\
\hline Healthcare & $\begin{array}{c}\text { Continuing medical and disaster relief services. } \\
\text { Focus on prevention and individualized health care. } \\
\text { Access to individualized life stage data using computerized } \\
\text { health platforms. } \\
\text { Telemedicine. }\end{array}$ \\
\hline Agriculture and Food & $\begin{array}{l}\text { Use of technology for crop growth and optimization. } \\
\text { Inclusion of different actors in the food value chain. } \\
\text { Using technology to automate logistics. }\end{array}$ \\
\hline Logistics & $\begin{array}{l}\text { Data sharing across the supply chain. } \\
\text { Personalized products to meet specific customer needs. } \\
\text { Service-oriented rather than hardware-oriented. }\end{array}$ \\
\hline Manufacturing and services & $\begin{array}{c}\text { Customers will be able to order items designed specifically for } \\
\text { their needs. }\end{array}$ \\
\hline Finance & $\begin{array}{l}\text { Support for small businesses to produce quality goods. } \\
\text { Diversifying financial services with digital technology. } \\
\text { Better distribution of funds across society. } \\
\text { Better access to financial services, based on the use of } \\
\text { cryptocurrency and token economy, such as blockchain. }\end{array}$ \\
\hline Public service & $\begin{array}{l}\text { Improve public administration services based on digitization and } \\
\text { better data sharing. } \\
\text { Establishing safety nets in response to priority safety areas. }\end{array}$ \\
\hline
\end{tabular}

The benefits of the idea of Society 5.0 should be enjoyed by all. Society 5.0 should be human-centered; it should strike a balance between economic progress and solving social problems through a system that largely integrates cyberspace and physical space. Japan, 
therefore, wants to be a model for a new society in which various social challenges can be solved by realizing the vision of Industry 4.0 in every industry and field of society. In this way, the society of the future will be one in which new values and services are continuously created, making people's lives more convenient while ensuring sustainable and balanced development [104]. The combination of the pillars of Industry 4.0 and Industry 5.0 and the artefacts of Society 5.0 are summarized in Table 2.

Table 2. Industry 4.0 vs. Industry 5.0 vs. Society 5.0.

\begin{tabular}{|c|c|c|}
\hline Industry 4.0 & Industry 5.0 & Society 5.0 \\
\hline \multicolumn{3}{|c|}{ Source } \\
\hline $\begin{array}{l}\text { High-Tech Strategy } 2020 \text { (German } \\
\text { government's technology } \\
\text { development strategy) } \\
\text { Strategic initiative Industry } 4.0 \\
\text { (recommendations of } \\
\text { representatives of German business, } \\
\text { industry, and science for the } \\
\text { implementation of a government } \\
\text { program shaping revolutionary } \\
\text { changes in industry) }\end{array}$ & $\begin{array}{c}\text { Industry } 5.0 \text { towards } \\
\text { sustainable, human-centric, } \\
\text { and resilient } \\
\text { European industry } \\
\text { European Commission } 2020\end{array}$ & $\begin{array}{c}\text { Japan Revitalization } \\
\text { Strategy } 2015 \\
\text { Japan Growth } \\
\text { Strategy } 2017\end{array}$ \\
\hline \multicolumn{3}{|c|}{ Scope of subject matter } \\
\hline $\begin{array}{c}\text { Smart Factory } \\
\text { Manufacturing-focused solutions } \\
\text { Mass customization } \\
\text { Servitization } \\
\text { Cyber-physical networking }\end{array}$ & $\begin{array}{l}\text { Humanization of industry } \\
\text { Human-centric } \\
\text { Sustainability } \\
\text { Resilience }\end{array}$ & Super-intelligent society \\
\hline
\end{tabular}

The Society 5.0 and Industry 5.0 concepts refer to a fundamental change in today's economy and society.

\section{Materials and Methods}

This paper presents the results of a survey, "Social and economic expectations of Society 5.0", which was conducted by the authors between 1 June 2021 and 15 September 2021. The survey was conducted using the CAWI method (standardized online interview using a computer). The research tool was a survey questionnaire consisting of 25 questions and a metric. The survey questions were closed, tabular, and complex. In the next part of the article, in the results chapter, selected results obtained in the study will be presented. The questionnaire was validated. A pilot survey was also conducted among 10 experts who have knowledge of the fourth industrial revolution. The questionnaire was adapted to their comments. The respondents are people living in different regions of Poland, so the study population can be considered infinite. A CAWI survey enabled the study of public opinion and the purpose of the article. The CAWI method was chosen due to the possibility of conducting the survey without the need for direct contact with the respondent, which, in the situation of COVID 19, is advisable. In addition, this method allowed the survey to be disseminated through social media.

Assuming a confidence level of 0.99 and an error of $10 \%$, it was determined that the minimum size of the general population should be 166 respondents. The study obtained 329 opinions, so it can be assumed that the information contained in the questionnaires received can be considered representative. The study involved 155 males and 174 females, the majority of the respondents reside in a medium-sized city and are between 19-25 years of age. Selected results of the selection of respondents are presented in Table 3. 
Table 3. Gender, age, and place of residence of the respondents.

\begin{tabular}{ccccccc}
\hline Age & \multicolumn{2}{c}{ Sex } & \multicolumn{4}{c}{ Place of Residence } \\
\hline & W & M & Village & Small Town & Medium City & Big City \\
\hline below 18 & 8 & 15 & 3 & 2 & 12 & 6 \\
19-25 & 77 & 62 & 14 & 36 & 46 & 43 \\
$26-35$ & 24 & 14 & 5 & 6 & 17 & 10 \\
$36-45$ & 32 & 24 & 3 & 16 & 24 & 13 \\
$46-55$ & 16 & 22 & 2 & 10 & 14 & 12 \\
$56-67$ & 14 & 15 & 6 & 5 & 2 & 8 \\
Over 67 & 3 & 3 & 0 & 2 & 125 & 94 \\
/sum & 174 & 155 & 33 & 77 & & \\
\hline
\end{tabular}

\section{Results}

In the first question, the respondents were asked to assess the strength of the impact (on the Likert scale, where level 1 meant no impact, and level 5 very significant impact) of the development of digitized industry on the various effects felt by Society 5.0. One of the significant threats the respondents considered was the influence of industrial development on environmental pollution, indicating it as very significant (44\%) and significant (33\%); only $1 \%$ of the respondents did not associate the development of the digitized industry with environmental pollution. Similarly, high concern about the depletion of natural resources was indicated respectively by respondents as very significant (35\%) and significant (33\%). It was related to the issue of rising prices of natural resources, such as crude oil and natural gas. The respondents did not show a strong relationship between industrial development and the prices of natural resources. $42 \%$ of respondents indicated the impact at a significant level and $33 \%$ of respondents considered the impact to be insignificant. The great concern may result from the assessment of the level of influence of industrial development on the increase in the level of technological unemployment; $46 \%$ of the respondents indicated a significant level, and $35 \%$ a very significant level. Excessive growth in the consumption of mobile means of communication and computers, resulting from the widespread digitization of economic processes, was declared to be significant by $38 \%$ of the respondents and to be very significant by $25 \%$ of the respondents. Industry dehumanization through autonomous intelligent machines and devices worried $39 \%$ of respondents (very significant level), and $45 \%$ indicated a significant level; 37\% (significant) and 38\% of the respondents (very significant) noted a decline in the sense of security in the field of cyberattacks. The fear of being addicted to personalized products was most often assessed as significant (48\% of respondents). Excessive virtualization of private life (the need for contact displaced by the possibilities of digital communication) was most often indicated as a concern at the levels of being significant (33\% of respondents) and very significant (32\% of the respondents). Similarly, the respondents pointed to the excessive virtualization of private life, which was most often assessed at the levels of being significant (37\%) and very significant (33\% of respondents). The respondents also considered the possibility of artificial intelligencecontrolled systems taking control over society as a significant concern. As many as $73 \%$ of respondents believe it is very significant and significant. Similarly, the respondents are afraid of changes in the social structure, especially those caused by the exclusion of people with low professional qualifications; $68 \%$ of the respondents considered it significant and very significant.

Another issue is the possibility of using stationary points of sale, the number of which may be limited due to the development of e-commerce. Most emphasize the possibility of such an impact (in total, $57 \%$ considered a significant and very significant impact). Only $27 \%$ of the respondents indicate that this may be a middling effect of industrial development. Interestingly, based on the answers, one cannot assign a characteristic response strictly for men or women.

Among all the listed consequences, the lack of a significant determination of the impact concerned consumers' addiction to new personalized products. A total of $50 \%$ considered 
it significant and very significant. As many as $15 \%$ of respondents indicated no influence, $18 \%$ a negligible influence, and $17 \%$ a middling level. The remaining concerns, the grade at level 1 (no impact), was chosen by only $1-6 \%$ of the respondents. This means that the respondents consider that major changes in the economy are related to the development of the digitized industry. Table 4 presents detailed answers to the question about the impact of the development of digitized industry on Society 5.0, and Figure 1 illustrates a graphic interpretation of the results obtained.

Table 4. The impact of the development of digitized industry on Society 5.0.

\begin{tabular}{|c|c|c|c|c|c|}
\hline Consequences & No Impact (1) & Negligible (2) & Middling (3) & Significant (4) & Very Significant (5) \\
\hline Environmental pollution (1) & $1 \%$ & $7 \%$ & $15 \%$ & $33 \%$ & $44 \%$ \\
\hline Depletion of natural resources (2) & $1 \%$ & $7 \%$ & $24 \%$ & $33 \%$ & $35 \%$ \\
\hline Increase in the prices of natural resources (crude oil, natural gas) (3) & $5 \%$ & $33 \%$ & $17 \%$ & $42 \%$ & $3 \%$ \\
\hline Increase in technological unemployment (4) & $1 \%$ & $5 \%$ & $13 \%$ & $46 \%$ & $35 \%$ \\
\hline $\begin{array}{l}\text { Increased consumption of mobile means of communication and } \\
\text { computer equipment (5) }\end{array}$ & $5 \%$ & $15 \%$ & $17 \%$ & $38 \%$ & $25 \%$ \\
\hline $\begin{array}{c}\text { Dehumanization of industry through the use of autonomous } \\
\text { intelligent machines and devices (6) }\end{array}$ & $2 \%$ & $2 \%$ & $12 \%$ & $45 \%$ & $39 \%$ \\
\hline Decline in the sense of security in the field of cyber attacks (7) & $3 \%$ & $5 \%$ & $17 \%$ & $37 \%$ & $38 \%$ \\
\hline $\begin{array}{l}\text { Consumer dependence on personalization (8) } \\
\end{array}$ & $15 \%$ & $18 \%$ & $17 \%$ & $42 \%$ & $8 \%$ \\
\hline Excessive virtualization of professional life (remote work) (9) & $3 \%$ & $10 \%$ & $22 \%$ & $33 \%$ & $32 \%$ \\
\hline $\begin{array}{c}\text { Excessive virtualization of private life (increased contact through } \\
\text { digital communication channels) (10) }\end{array}$ & $2 \%$ & $8 \%$ & $20 \%$ & $37 \%$ & $33 \%$ \\
\hline $\begin{array}{c}\text { Control over society through systems controlled by artificial } \\
\text { intelligence (11) }\end{array}$ & $5 \%$ & $12 \%$ & $10 \%$ & $31 \%$ & $42 \%$ \\
\hline $\begin{array}{l}\text { Changes in the social structure, especially due to the exclusion of } \\
\text { people with low professional qualifications (12) }\end{array}$ & $3 \%$ & $12 \%$ & $17 \%$ & $35 \%$ & $33 \%$ \\
\hline Decrease in the number of stationary points of sale (13) & $6 \%$ & $10 \%$ & $27 \%$ & $37 \%$ & $20 \%$ \\
\hline
\end{tabular}

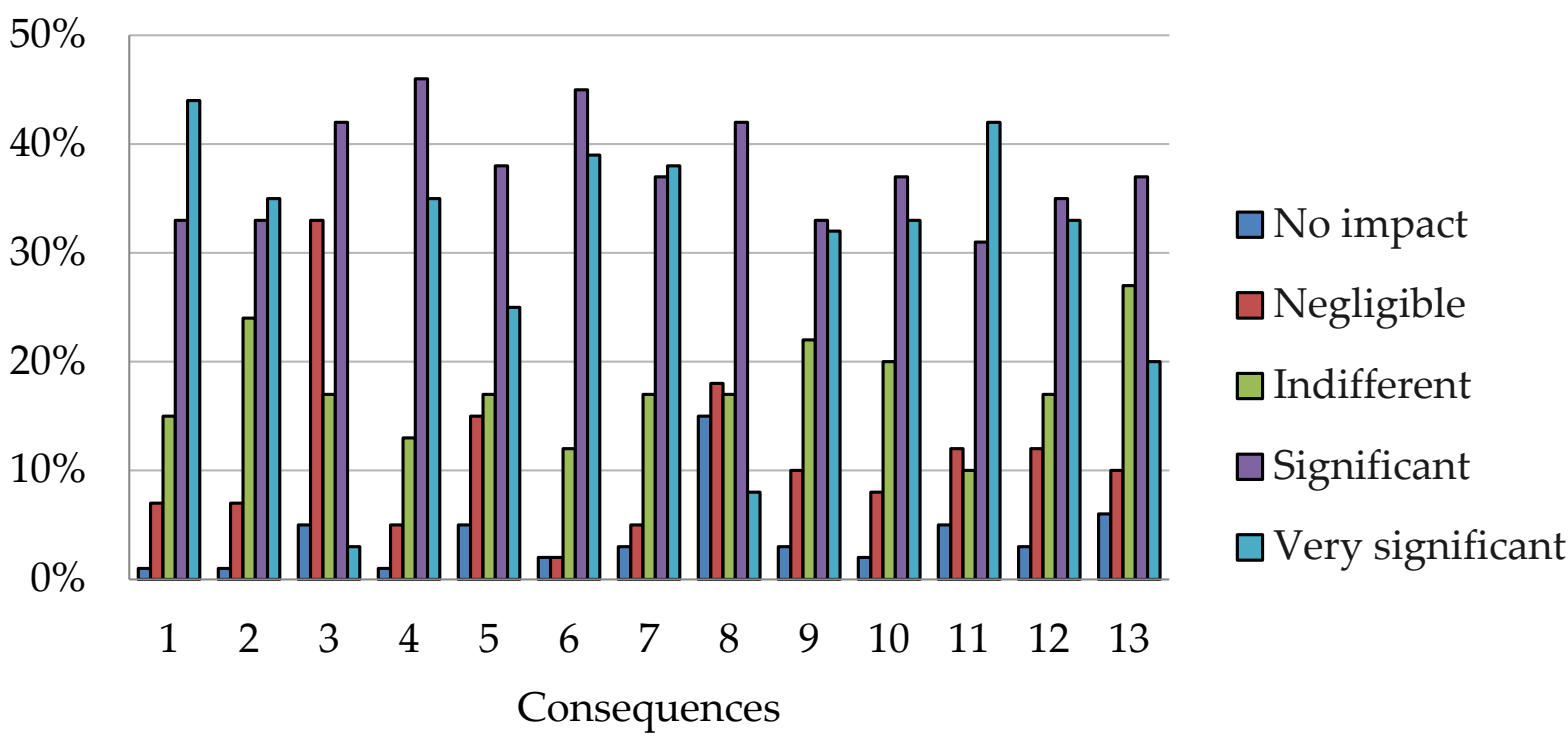

Figure 1. Influence of the development of digitized industry on society.

In the next question, the respondents assessed the possible impact of actions limiting negative consequences caused by the development of the digitized industry. The Likert scale (1-no impact, 5-very significant) was used for evaluation. The activities with a very significant impact on reducing the negative effects of the digitized industry include mainly: implementation of share economics principles (e.g., car-sharing) (42\%), implementation of circular economy principles (40\%), decarbonization of the economy (35\%), training and education system (33\%), socially responsible marketing (33\%), and increase in production on order $(30 \%)$. The most frequently considered significant actions by the respondents were: employment restructuring system in industry (48\%); decarbonization of the economy $(45 \%)$, increase in renewable energy production and socially responsible marketing (42\%), implementation of share economics (car-sharing) (36\%), implementation of circular economy principles (36\%), training system and education $(35 \%)$, an increase in personalized 
production (34\%), and an increase in production made to order (34\%). No activity achieved more than a $30 \%$ response for a neutral effect. On the other hand, as a level irrelevant for limiting the adverse effects of the development of digitized industry- $33 \%$ of respondents considered stimulating the reduction of production and consumption. The analysis of the results shows that, rather, all activities have an impact on reducing adverse effects. The answer of "no influence", in any case, did not receive more than $25 \%$ of the responses. Table 5 presents a detailed distribution of responses, and Figure 2 shows the answers.

Table 5. Activities limiting the negative effects of the development of a digitized industry.

\begin{tabular}{|c|c|c|c|c|c|}
\hline Activities & No Impact (1) & Negligible (2) & Middling (3) & Significant (4) & Very Significant (5) \\
\hline Decarbonization of the economy & $5 \%$ & $10 \%$ & $5 \%$ & $45 \%$ & $35 \%$ \\
\hline Increase in the production of renewable energy & $3 \%$ & $10 \%$ & $17 \%$ & $42 \%$ & $28 \%$ \\
\hline Training and education system & $10 \%$ & $10 \%$ & $12 \%$ & $35 \%$ & $33 \%$ \\
\hline Employment restructuring system in industry & $7 \%$ & $7 \%$ & $14 \%$ & $48 \%$ & $24 \%$ \\
\hline Implementation of the circular economy principles & $5 \%$ & $7 \%$ & $12 \%$ & $36 \%$ & $40 \%$ \\
\hline Encouraging the reduction of production and consumption & $22 \%$ & $33 \%$ & $23 \%$ & $12 \%$ & $10 \%$ \\
\hline Increase in personalized production & $10 \%$ & $12 \%$ & $15 \%$ & $34 \%$ & $29 \%$ \\
\hline Implementation of share economics principles (e.g., car-sharing) & $5 \%$ & $7 \%$ & $10 \%$ & $36 \%$ & $42 \%$ \\
\hline Socially responsible marketing & $6 \%$ & $8 \%$ & $11 \%$ & $42 \%$ & $33 \%$ \\
\hline Limitation of production to the warehouse & $15 \%$ & $17 \%$ & $18 \%$ & $28 \%$ & $22 \%$ \\
\hline Increase in production to order & $10 \%$ & $12 \%$ & $14 \%$ & $34 \%$ & $30 \%$ \\
\hline
\end{tabular}

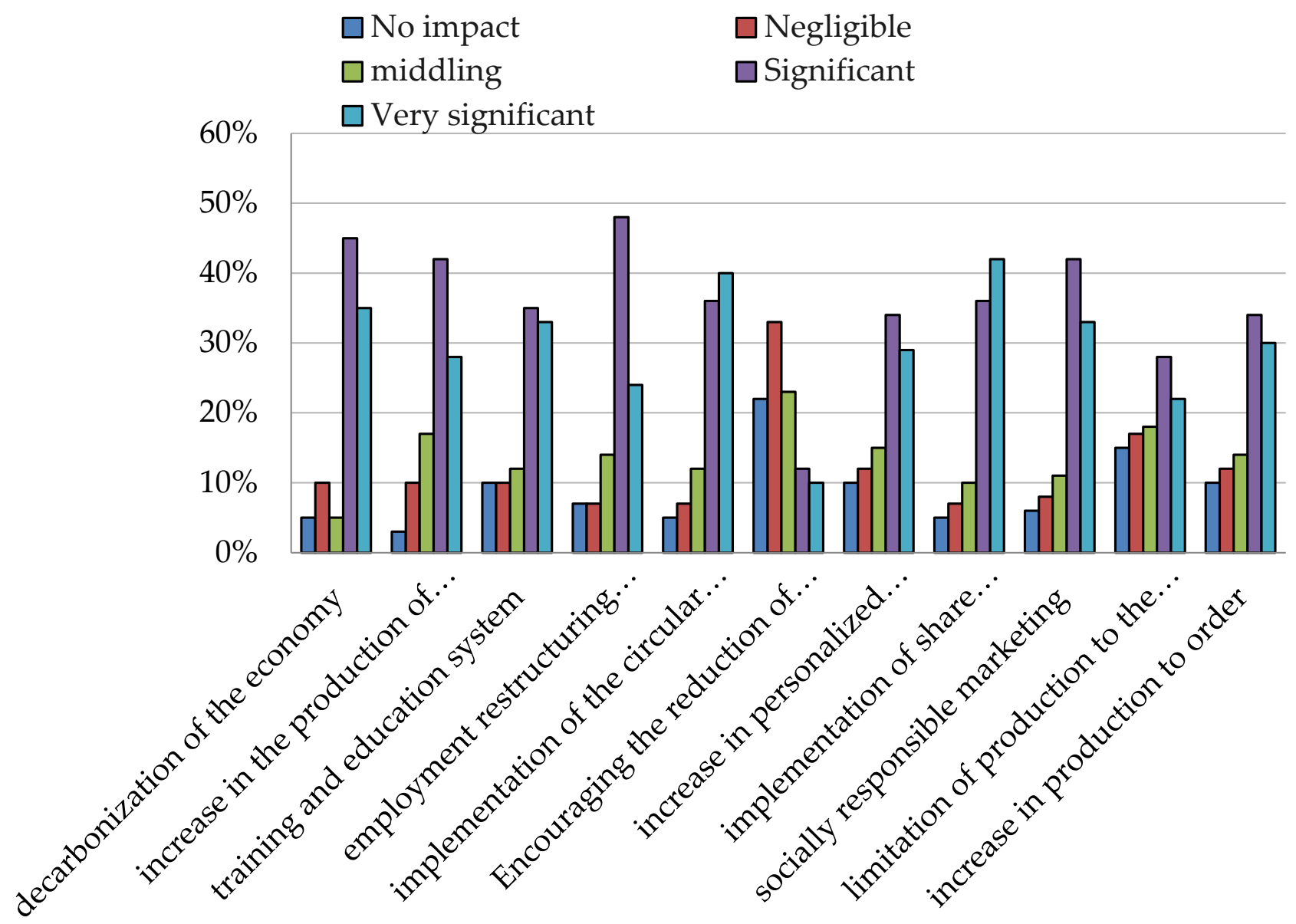

Figure 2. Activities limiting the negative effects of the development of a digitized industry.

In the other part of the survey, the respondents expressed their opinion on the activities that may increase the resistance to disruptions of the digitized industry in crisis situations (to indicate several answers was allowed). According to the respondents, the most important factor for resilience is the digitization of the economy ( 237 responses / $72 \%$ ), use of local and regional potential (production resources) (220 answers/67\%), and development of network cooperation of local (national) small and medium-sized enterprises 
(155 responses/47\%). The least influence on resistance was assessed by the respondents as the popularization of remote work (82 responses $/ 25 \%$ ). All obtained responses are shown in Figure 3.

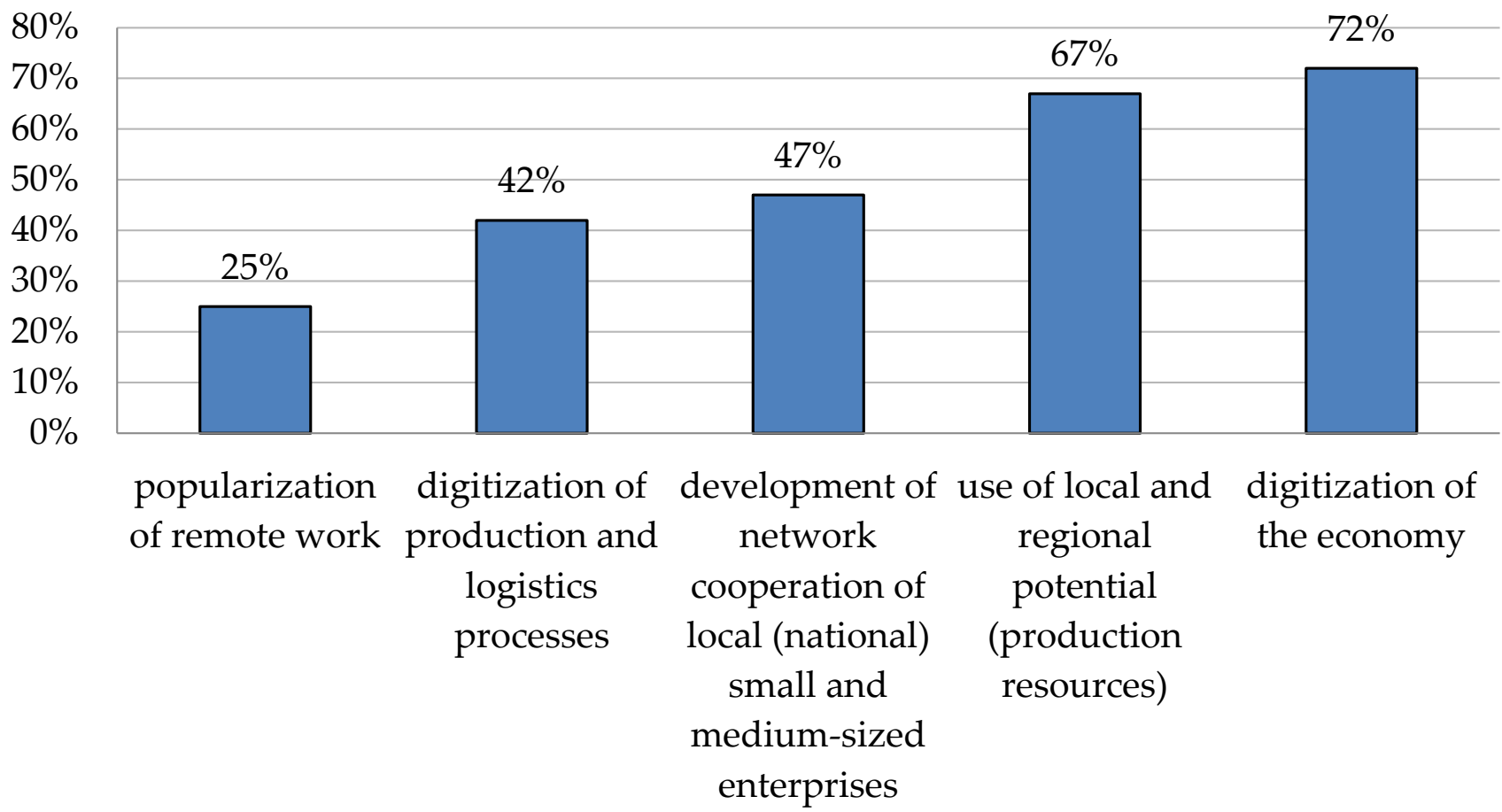

Figure 3. Activities increasing the industry's resilience to disruptions in crises.

The next question concerned the assessment of the impact of the implemented esolutions on the increase in the quality of life of the respondents (the answer was based on the Likert scale; 1 -no impact, 5-very significant impact). The detailed distribution of responses is shown in Table 6. The respondents emphasized that the e-government electronic inbox - ePUAP, e-pit-had a significant impact on their quality of life $(37 \%$ of respondents), and $27 \%$ indicated that it was a very significant impact. Similarly, the introduction of the e-patient solution (patient's online account) had a significant impact on $42 \%$ of respondents, as $18 \%$ of respondents indicated a very significant impact. Ecommerce (online stores) had a significant impact on improving the quality of life among $43 \%$ of respondents, significantly among $33 \%$ of respondents. Only $4 \%$ of respondents indicated that this e-solution did not matter. Due to widespread digitization, electronic banking solutions are also very popular, which facilitate the servicing of customers' bank accounts. In this case, $25 \%$ of the respondents indicated a very significant impact, $32 \%$ of the respondents rated the impact as significant, and $24 \%$ of the respondents rated the impact to be middling. Almost half (47\%) of the respondents assessed that e-transport services (e.g., Uber, car-sharing, city bikes) had a significant impact on the improvement of their quality of life, and only $4 \%$ considered that this solution did not matter/does not affect them in terms of their quality of life. Electronic payments significantly affected the quality of life of $33 \%$ of respondents, very significantly for $27 \%$ of respondents. Figure 4 shows the answers given. 
Table 6. Impact of e-solutions on the digitization of processes and quality of life.

\begin{tabular}{|c|c|c|c|c|c|}
\hline E-Solutions for Digitization of Processes & No Impact (1) & Negligible (2) & Middling (3) & Significant (4) & Very Significant (5) \\
\hline E-government, electronic inbox-epuap, e-pit, etc. & $7 \%$ & $15 \%$ & $14 \%$ & $37 \%$ & $27 \%$ \\
\hline E-patient (patient's online account) & $5 \%$ & $18 \%$ & $17 \%$ & $42 \%$ & $18 \%$ \\
\hline E-commerce (online stores) & $4 \%$ & $8 \%$ & $12 \%$ & $33 \%$ & $43 \%$ \\
\hline Electronic banking & $9 \%$ & $10 \%$ & $24 \%$ & $32 \%$ & $25 \%$ \\
\hline E-transport services (Uber, car-sharing, city bikes) & $4 \%$ & $16 \%$ & $21 \%$ & $47 \%$ & $12 \%$ \\
\hline E-pay solutions & $8 \%$ & $9 \%$ & $23 \%$ & $33 \%$ & $27 \%$ \\
\hline
\end{tabular}

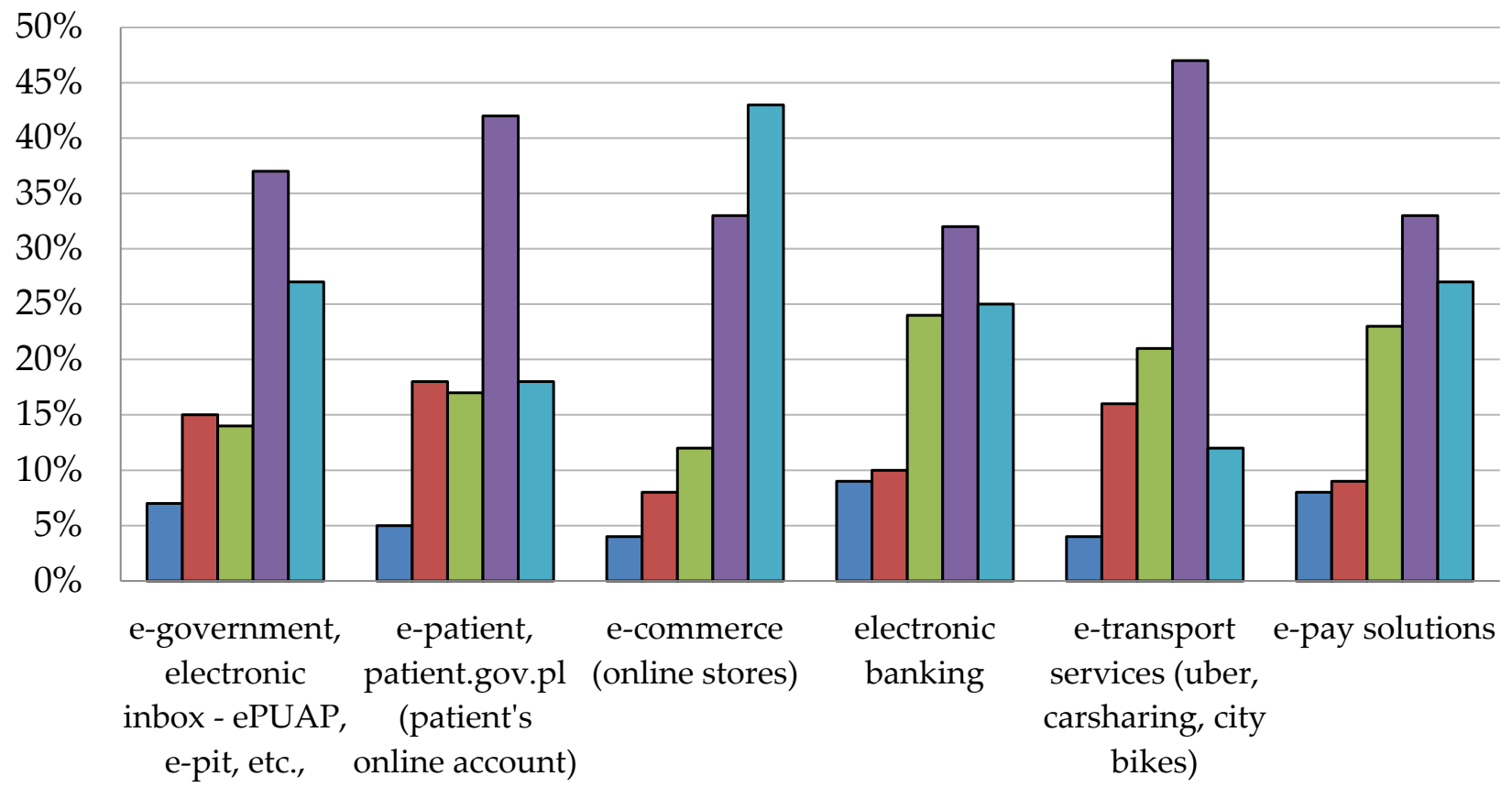

Figure 4. Impact of e-solutions on the digitization of processes and quality of life.

The purpose of the last question (multiple choice, semi-open question) was to find out what the respondents thought about the benefits of the fourth industrial revolution (Figure 5). Most believe that the fourth industrial revolution will have a positive impact on enabling the production of highly personalized products at a low purchase price (77\%); better adjustment of the product to current customer needs (74\%); increasing the level of sustainable consumption, e.g., by using personalized products $(69 \%)$; the possibility of solving the problems of a lack of low-skilled workers (machine operators), thanks to Industry 4.0 solutions $(64 \%)$; increased attention to aspects related to sustainable development $(61 \%)$; increasing the availability of a wide range of products ( $47 \%)$; higher levels of timely execution of orders (orders) (38\%); enabling active customer involvement in the design of new products $(30 \%)$. Among the less frequently chosen answers, there were opportunities related to reducing the number of intermediaries in the supply chain $(26 \%)$; increasing the flexibility of supply chains (20\%); the possibility of developing new business models based on design products manufactured by Industry 4.0 enterprises (14\%); an increase of the quality of life level by purchasing and using personalized products $(11 \%)$, and the possibility of creating new values by the enterprises $(8 \%)$. 


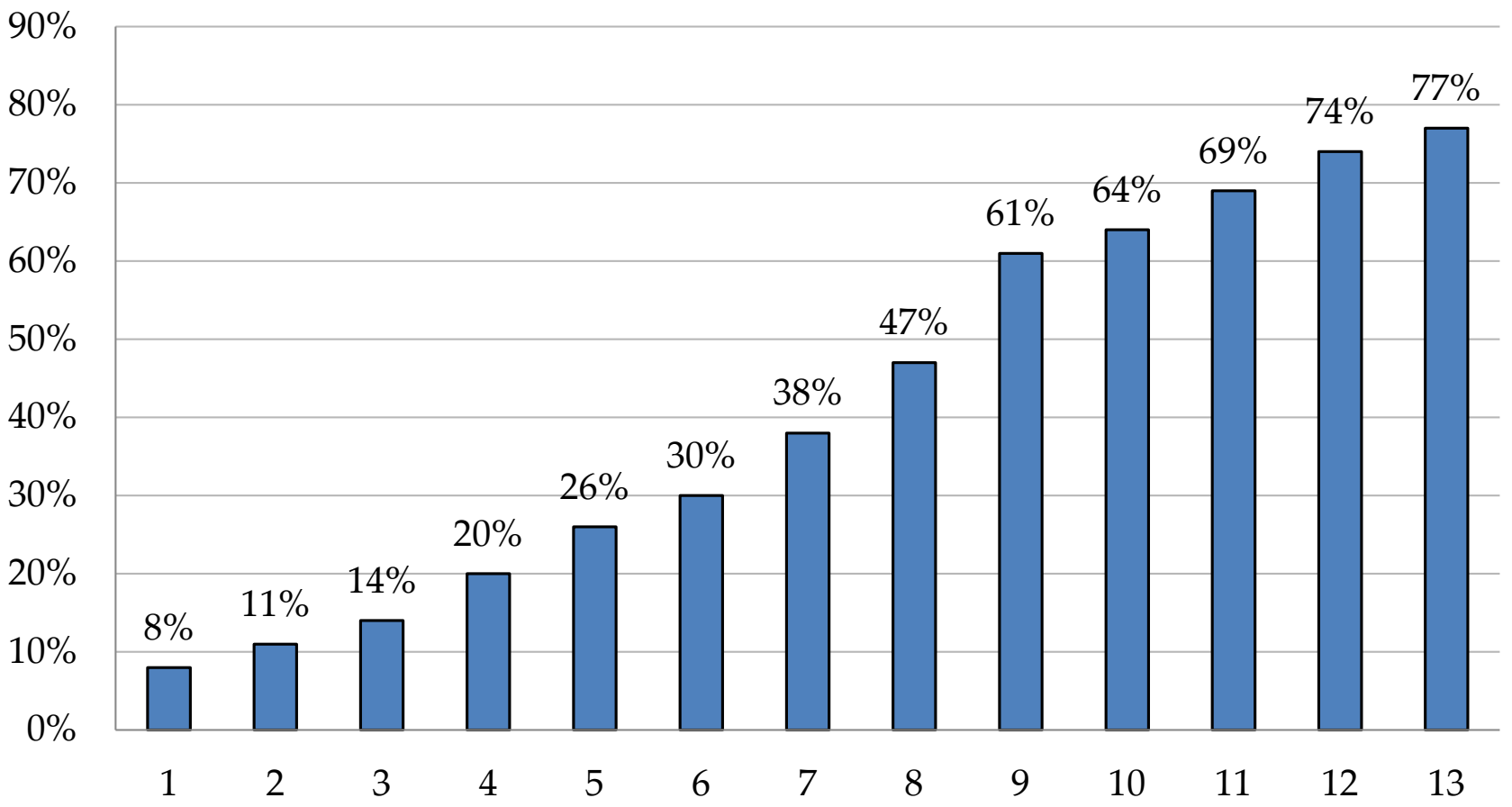

Figure 5. Expected benefits of the fourth industrial revolution. Legend: 1 -creating new values by enterprises; 2-increasing the level of quality of life by using personalized products; 3-development of new business models based on I4.0; 4-increasing the flexibility of supply chains; 5-reducing participants in the supply chain; 6-active participation in designing of personalized products; 7-higher levels of timeliness of executed orders (orders); 8 -increasing the availability of a wide range of products; 9-paying more attention to the aspects of sustainable development; 10 -solving the problem of the lack of low-skilled workers (machine operators) on the market; 11-increasing the level of sustainable consumption; 12 - better adaptation of the product to the customer's needs; 13-highly personalized product production, available at a low price.

The survey research shows that the public is highly aware of the activities limiting the adverse effects of the development of digitized industry, as presented in Table 5. A total of 3619 responses were obtained during the study, including 2364 significant and very significant responses. Most people indicated the following features: decarbonization of the economy (264 responses), implementation of share economics (car-sharing) (257), implementation of circular economy principles (251), socially responsible marketing (247), and an employment restructuring system in industry (237 respondents). According to the respondents, the Pareto chart (Figure 6) shows the activities that have the most significant impact on reducing the adverse effects of the development of a digitized industry. In the respondents' opinion, the most important activities with the strongest impact were identified. The ranking of the causes influencing the process of limiting the negative impact of the development of a digitized industry due to their strength of influence can be used by policymakers to apply an appropriate sustainable development strategy. 


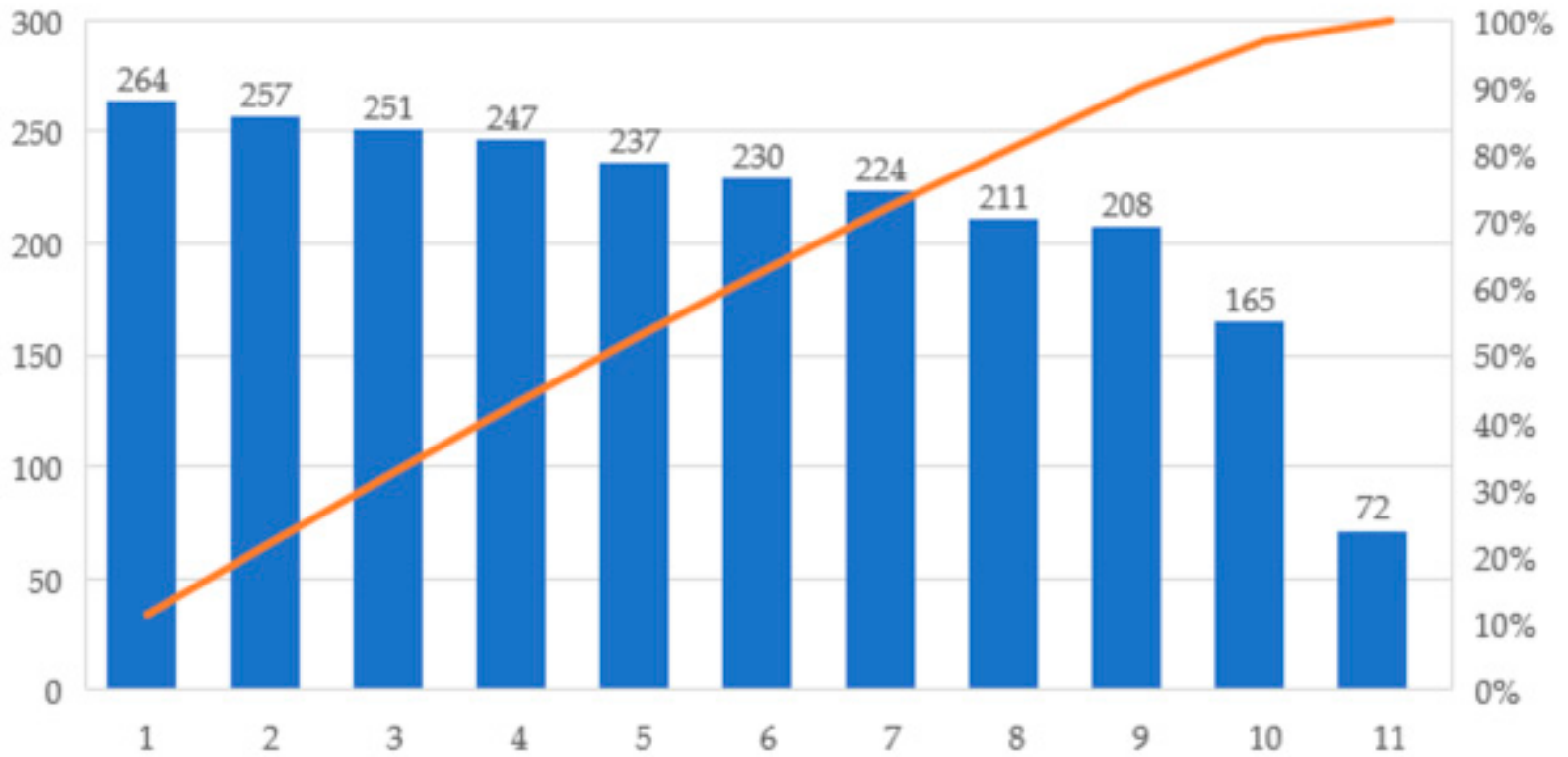

Figure 6. Pareto diagram of responses regarding actions to mitigate the negative effects of the development of the digitized industry. Legend: 1-decarbonization of the economy; 2-implementation of share economics principles (e.g., car-sharing); 3-implementation of the circular economy principles; 4-socially responsible marketing; 5-employment restructuring system in industry; 6-increase in the production of renewable energy; 7-training and education system; 8-increase in production to order; 9-increase in personalized production; 10-limitation of production "make to stock"; 11 - encouraging the reduction of production and consumption.

\section{Discussion}

In Industry 4.0, the working environment is determined by integrated and advanced production technologies, equipped with sensors that track the operation of machines and communication systems that report data and conduct advanced simulations. The currently observed dynamic increase in the digitization of enterprises, caused by the implementation of Industry 4.0 technologies and the orientation of enterprises towards the dehumanization of production systems, has caused many concerns of employees, society, and even governments. Man's role in future industry and society is very rarely mentioned. Hence, the article identifies social and economic expectations in the context of the development of digitized industry and discusses the need for the transformation process of the Industry 4.0 concept into Industry 5.0.

For society to actively support the further development of Economy 4.0 and Industry 4.0, it must understand the need for changes that should be carried out with the quality of life and the elimination of threats in mind. Hence, authors have attempted to assess the impact of digitized industry on the functioning of society in the areas most often identified in the literature as potential problems [7,92-95,101]. The conducted observations can confirm the dehumanization of industry, as presented in the considerations of many authors through the use of autonomous intelligent machines and devices, the increase in technological unemployment, environmental pollution, and cybersecurity (cyber-attacks), and control over society through controlled systems by artificial intelligence. Currently, the literature more and more often develops the concept of Industry 5.0, aimed at reversing the dehumanization of industry and taking into account the crucial role of man in society. The Industry 5.0 concept is closer to sustainable development and considers society's needs.

People must see the digitization of industry as a path to development and the quality of life of the average person, which is correlated with the values of Society 5.0. However, most society does not have access to information about a modern industrial plant, which creates a sense of fear in the face of information about factories with robots taking jobs away from people. In such a situation, it is easy to find social reluctance and anxiety 
towards technological progress. Only a few know that, for example, as the productivity of agriculture and production increases, employment in this sector decreases, but there are also changes in the structure of employment, which generally does not increase unemployment in the economy [92]. Globalization and the development of new technologies are becoming a motivating factor for innovation and creativity in new business models, new services, and the generation of new jobs.

Globalization and the development of Economy 4.0, supported by the development of Industry 4.0 and Industry 5.0, enable the creation of new value. This is all thanks to the technological solutions that are defined as the pillars of Industry 4.0. For enterprises, it is an opportunity to create a network of values in which IT systems and cyber-physical systems of intelligent machines throughout the entire supply chain will automatically exchange data with each other, which will result in the transfer to a higher level of the "just-in-time" production model. For customers, creating new value is associated with the possibility of purchasing highly personalized products at the prices of mass-produced products. However, as shown by the results of the conducted research, only $8 \%$ of respondents perceive these possibilities (Figure 5).

Geopolitical changes and natural crises such as the COVID-19 pandemic have highlighted the fragility of our current approach to globalized production. High flexibility and agility in production require efficient supply chains. Hence, resilience becomes essential. Resilience refers to the need to develop the stability of industrial output, better safeguard it from disruptions, and ensure that it can provide and support critical infrastructure during the crisis. It should be sustainable by achieving resilience in strategic value chains, agile production capabilities, and business processes. Basic social needs, such as health care or security, are particularly noteworthy $[60,62]$. The adjective "resilient" has been used by the EC [31]. The popularity of the adjective "resilient" is growing. It is considered valuable to describe the features of the Industry 5.0 concept, especially in the effects of the COVID-19 pandemic on economies, societies, and industries.

To become a resilient supplier of prosperity, modern industry should ensure that production respects our planet's resources and puts the welfare of industrial workers and society at the center of attention. The challenge for developing economies is to strike a balance between economic growth and the pursuit of environmental well-being. To achieve this goal, it is necessary to balance three aspects of development: economic, social, and ecological. This forces continuous product improvement and the optimization of production technology. With the lowest possible consumption of raw materials and impact on the natural environment, products with the best performance parameters are economically viable. According to the respondents, the most important factor for industrial resilience may be the digitization of the economy, the use of local and regional potential (production resources), and the development of the network cooperation of local (national) small and medium-sized enterprises. This means confirmation of the orientation trend towards the need to shorten supply chains, which, in the COVID-19 pandemic, have become vulnerable to disruptions, and an orientation towards the development of one's own, regional, and local resources. At the same time, the respondents emphasized the importance of the digitization of economic processes, which may also be the effect of observations during the COVID-19 pandemic.

Despite the concerns and difficulties perceived by the respondents, they see many benefits in the concept of Industry 4.0. The most important ones include: personalization of production and attractive prices of products, a better adaptation of the product offer to the current needs of the customer, increasing the level of sustainable consumption, replacing low-skilled workers (machine operators) who are currently missing on the market and facilitating the achievement of sustainable development and, thus, reducing the environmental pollution. 


\section{Conclusions}

Nowadays, the world faces many technological, economic, and geopolitical changes and those in the way of thinking and world views. Each change creates new opportunities but also challenges and concerns. Globalization and ICT technologies promote the ubiquitous digitalization of processes. Today, industry is oriented towards the implementation of CPSs oriented towards the use of autonomous, intelligent machines and devices but not all service spheres of the economy. This means structural changes in the economy, affecting both society and business. New conditions for functioning in Economy 4.0 require changes in business models, an orientation to personalized production, the restructuring of economic processes, solving the problem of short-term structural unemployment, and the need to network the economy. The COVID-19 pandemic paradoxically showed that the current level of digitization of processes had avoided a deep crisis in many areas of the economy and education but, at the same time, exposed the weaknesses of globalization and the problems of human adaptation to the digitization and lack of resilience of the industry to the disruption of global supply chains.

Considerations carried out in the article, supported by literature analysis and survey research, show the need for the humanization of the industry of the future so that human beings play a key role in it. The development of a new concept is based on the needs of Society 5.0 and Economy 4.0, with particular emphasis on the principles of sustainable development and quality of life. Noteworthy are the identified actions that should be taken to reduce the negative effects of the digitized industry. Decision-makers in EU governments should intensify actions supporting the following policies: decarbonization of the economy, an increase of renewable energy production, implementation of the principles of a sharing economy and the circular economy. In addition, specialized training and education programs are required as well as a system of worker protection during employment restructuring in industry, which will prepare society for the ubiquitous digitization of both industry and the economy. An important aspect is resilience to all kinds of disruptions. Society recognizes the need for the digitization of the economy, the use of local and regional potential (production resources), and the development of the network cooperation of local (national) small and medium-sized enterprises.

The limitation of the conducted research is narrowing down the study to representative groups of Polish society. In the future, representatives of other EU countries should be included. The presented research results are the basis for further, more in-depth research on the social and economic effects of the implementation of digitization in industry and the economy. The direction of further research should be the development of programs to support the humanization of the digitized industry. An important element is to develop models of Economy 4.0, which will be able to combine ubiquitous digitalization with human factors, resilience, and sustainability.

Author Contributions: The main activities of the team of authors can be described as follows: Conceptualization, S.S., S.G.; methodology, S.S., S.G.; software, S.S., S.G., M.S.; validation, S.S., S.G.; formal analysis, S.S., S.G.; investigation, S.S., S.G.; resources, S.S., S.G.; data curation, S.S., S.G.; writing—original draft preparation, S.S., S.G.; writing—review and editing, S.S., S.G.; visualization, S.S., S.G., supervision, S.S., S.G., M.S.; funding acquisition, S.S., S.G., M.S. All authors have read and agreed to the published version of the manuscript.

Funding: Research was funded by the grants KEGA 016TUKE-4/2020 "Projects of applied research as a means for the development of new models of education in the study program of industrial logistics" and VEGA 1/0317/19 "Research and development of new smart solutions based on the principles of Industry 4.0, logistics, 3D modelling and simulation for streamlining production in the mining and building industry".

Institutional Review Board Statement: Not applicable.

Informed Consent Statement: Not applicable, because participation in the survey was voluntary and anonymous, no confidential data was collected about the respondents. 
Data Availability Statement: The study analyzed publicly available datasets available in Web of Science and Scopus databases and the quantitative data collected using the CAWI method.

Conflicts of Interest: The authors declare no conflict of interest.

\section{References}

1. Romero, D.; Noran, O.; Stahre, J.; Bernus, P.; Fast-Berglund, A. Towards a Human-Centred Reference Architecture for Next Generation Balanced Automation Systems: Human-Automation Symbiosis. Collab. Hyperconnected World 2015, 460, 556-566. [CrossRef]

2. Longo, F.; Padovano, A.; Umbrello, S. Value-Oriented and Ethical Technology Engineering in Industry 5.0: A Human-Centric Perspective for the Design of the Factory of the Future. Appl. Sci. 2020, 10, 4182.

3. Grabowska, S. Smart Factories in the age of Industry 4.0. Manag. Syst. Prod. Eng. 2020, 28, 2. [CrossRef]

4. Luthra, S.; Mangla, S.K. Evaluating challenges to Industry 4.0 initiatives for supply chain sustainability in emerging economies. Process Saf. Environ. Prot. 2018, 117, 168-179. [CrossRef]

5. De Sousa Jabbour, A.B.L.; Jabbour, C.J.C.; Godinho Filho, M.; Roubaud, D. Industry 4.0 and the circular economy: A proposed research agenda and original roadmap for sustainable operations. Ann. Oper. Res. 2018, 270, 273-286. [CrossRef]

6. Pagoropoulos, A.; Pigosso, D.C.; McAloone, T.C. The emergent role of digital technologies in the Circular Economy: A review. Procedia CIRP 2017, 64, 19-24. [CrossRef]

7. Saniuk, S.; Grabowska, S.; Gajdzik, B. Social Expectations and Market Changes in the Context of Developing the Industry 4.0 Concept. Sustainability 2020, 12, 1362. [CrossRef]

8. Rüßmann, M.; Lorenz, M.; Gerbert, P.; Waldner, M.; Justus, J.; Engel, P.; Harnisch, M. Industry 4.0: The Future of Productivity and Growth in Manufacturing Industries; Boston Consult, Group 9: Boston, MA, USA, 2015; pp. 54-89.

9. Hermann, M.; Pentek, T.; Otto, B. Design Principles for Industrie 4.0 Scenarios. In Proceedings of the 49th Hawaii International Conference on System Sciences (HICSS), Koloa, HI, USA, 5-8 January 2016; pp. 3928-3937.

10. Dalenogarea, L.S.; Beniteza, G.B.; Ayalab, N.F.; Franka, A.G. The expected contribution of Industry 4.0 technologies for industrial performance. Int. J. Prod. Econ. 2018, 204, 383-394. [CrossRef]

11. Sartal, A.; Bellas, R.; Mejías, A.M.; García-Collado, A. The sustainable manufacturing concept, evolution and opportunities within Industry 4.0: A literature review. Adv. Mech. Eng. 2020, 12, 1687814020925232. [CrossRef]

12. Wee, D.; Kelly, R.; Cattel, J.; Breunig, M. Industry 4.0: How to Navigate Digitization of the Manufacturing Sector; McKinsey Company: Chicago, IL, USA, 2015.

13. Machado, C.G.; Winroth, M.P.; Da Silva, E.H.D.R. Sustainable manufacturing in Industry 4.0: An emerging research agenda. Int J. Prod. Res. 2020, 58, 1462-1484. [CrossRef]

14. Wang, S.; Wan, J.; Li, D.; Zhang, C. Implementing Smart Factory of Industrie 4.0: An Outlook. Int. J. Distrib. Sens. Netw. 2016, 12, 3159805. [CrossRef]

15. Kolberg, D.; Zühlke, D. Lean Automation enabled by Industry 4.0 Technologies. IFAC-PapersOnLine 2015, 48, 1870-1875. [CrossRef]

16. De Sousa Jabbour, A.B.L.; Jabbour, C.J.C.; Foropon, C.; Godinho Filho, M. When titans meet-Can industry 4.0 revolutionise the environmentally-sustainable manufacturing wave? The role of critical success factors. Technol. Forecast. Soc. Chang. 2018, 132, 18-25. [CrossRef]

17. Piwowar-Sulej, K.; Krzywonos, M.; Kwil, I. Environmental entrepreneurship-Bibliometric and content analysis of the subject literature based on H-Core. J. Clean. Prod. 2021, 295, 126277. [CrossRef]

18. Enyoghasi, C.; Badurdeen, F. Industry 4.0 for sustainable manufacturing: Opportunities at the product, process, and system levels. Resour. Conserv. Recycl. 2021, 166, 105362. [CrossRef]

19. Stock, T.; Seliger, G. Opportunities of Sustainable Manufacturing in Industry 4.0. Procedia CIRP 2016, 40, 536-541. [CrossRef]

20. Bag, S.; Pretorius, J.H.C. Relationships between industry 4.0, sustainable manufacturing and circular economy: Proposal of a research framework. Int. J. Organ. Anal. 2020. [CrossRef]

21. Kagermann, H.; Wahlster, W.; Helbig, J. Recommendations for Implementing the Strategic Initiative INDUSTRIE 4.0. In Final Report of the Industrie 4.0 WG. 2013. Available online: https:/ / www.din.de/blob/76902/e8cac883f42bf28536e7e8165993f1fd/ recommendations-for-implementing-industry-4-0-data.pdf (accessed on 17 December 2021).

22. Gholami, H.; Saman, M.Z.M.; Sharif, S.; Khudzari, J.M.; Zakuan, N.; Streimikiene, D.; Streimikis, J. A General Framework for Sustainability Assessment of Sheet Metalworking Processes. Sustainability 2020, 12, 4957. [CrossRef]

23. Buer, S.-V.; Strandhagen, J.O.; Chan, F.T.S. The link between Industry 4.0 and lean manufacturing: Mapping current research and establishing a research agenda. Int. J. Prod. Res. 2018, 56, 2924-2940. [CrossRef]

24. Varela, L.; Araújo, A.; Ávila, P.; Castro, H.; Putnik, G. Evaluation of the Relation between Lean Manufacturing, Industry 4.0, and Sustainability. Sustainability 2019, 11, 1439. [CrossRef]

25. Menon, S.; Shah, S.; Coutroubis, A. Impacts of I4.0 on sustainable manufacturing to achieve competitive advantage. In Proceedings of the 8th International Conference on Operations and Supply Chain Management, Cranfield, UK, 9-12 September 2018.

26. Kamble, S.S.; Gunasekaran, A.; Gawankar, S.A. Sustainable Industry 4.0 framework: A systematic literature review identifying the current trends and future perspectives. Process Saf. Environ. Prot. 2018, 117, 408-425. [CrossRef] 
27. Song, Z.; Moon, Y. Assessing sustainability benefits of cybermanufacturing systems. Int. J. Adv. Manuf. Technol. 2016, 90, 1365-1382. [CrossRef]

28. Bluszcz, A.; Manowska, A. Differentiation of the Level of Sustainable Development of Energy Markets in the European Union Countries. Energies 2020, 13, 4882. [CrossRef]

29. Bonilla, S.H.; Silva, H.R.; Terra da Silva, M.; Franco Gonçalves, R.; Sacomano, J.B. Industry 4.0 and sustainability implications: A scenario-based analysis of the impacts and challenges. Sustainability 2018, 10, 3740. [CrossRef]

30. Terlau, W.; Hirsch, D. Sustainable Consumption and the Attitude-Behaviour-Gap Phenomenon-Causes and Measurements towards a Sustainable Development. Int. J. Food Syst. Dyn. 2015, 6, 159-174.

31. Industry 5.0 Towards A Sustainable, Human Centric and Resilient European Industry, p. 14. European Commission, Brussels, Manuscript Completed in January 2021. Available online: https://op.europa.eu/en/publication-detail/-/publication/aed3280d70fe-11eb-9ac9-01aa75ed71a1/language-en/format-PDF/source-search (accessed on 17 December 2021).

32. Lasi, H.; Fettke, P.; Kemper, H.G.; Feld, T.; Hoffmann, M. Industry 4.0. Bus. Inf. Syst. Eng. 2014, 6, 239-242. [CrossRef]

33. Olszewski, A.; Pawlewski, P. Stakeholder Involvement Added Value Indicators in IT Systems Design for Industry 4.0 Digital Innovation Hubs. In Smart and Sustainable Supply Chain and Logistics-Trends, Challenges, Methods and Best Practices; Springer: Cham, Switzerland, 2020.

34. Bauernhansl, T. Die Vierte Industrielle Revolution-Der Weg in ein wertscha_endes Produktionsparadigma. In Industrie 4.0 in Produktion, Automatisierung und Logistik-Anwendung, Technologien, Migration; Bauernhansl, T., ten Hompel, M., VogelHeuser, B., Eds.; Springer: Wiesbaden, Germany, 2015; pp. 5-35.

35. Azmi, A.N.; Kamin, Y.; Noordin, M.K.; Nasir, A.N.M. Towards industrial revolution 4.0: Employers' expectations on fresh engineering graduates. Int. J. Eng. Tech. 2018, 7, 267-272.

36. Pekarcikova, M.; Trebuna, P.; Kliment, M.; Dic, M. Solution of Bottlenecks in the Logistics Flow by Applying the Kanban Module in the Tecnomatix Plant Simulation Software. Sustainability 2021, 13, 7989. [CrossRef]

37. Bauernhansl, T.; Hompel, M.; Vogel-Henser, B. Industrie 4.0 in Produkten. Automatisierung und Logistik; Springer: Wiesbaden, Germany, 2014

38. Bechtold, J.; Kern, A.; Lauenstein, C.; Bernhofer, L. Industry 4.0-The Capgemini Consulting View. Available online: https: / / www.de.capgemini-consulting.com/resource-file-access/resource/pdf/capgemini-consulting-Industry-4.0_0.pdf. (accessed on 2 December 2021).

39. Berger, R. The Industrie 4.0 Transition Quantified. How the Fourth Industrial Revolution Is Reshuffling the Economic, Social and Industrial Model; Roland Berger: Munich, Germany, 2016.

40. Brousell, D.R.; Moad, J.R.; Tate, P. The Next Industrial Revolution: How the Internet of Things and Embedded, Connected, Intelligent Devices will Transform Manufacturing. Frost \& Sullivan, A Manufacturing Leadership White Paper 2014. Available online: https://www.allegient.com/wp-content/uploads/FS_Industrial_revolution.pdf (accessed on 2 December 2021).

41. Erboz, G. How to Define Industry 4.0: The Main Pillars of Industry 4.0. 2017. Available online: https://www.researchgate.net/ publication/326557388_How_To_Define_Industry_40_Main_Pillars_Of_Industry_40 (accessed on 5 December 2021).

42. Fatorachian, H.; Kazemi, H. A critical investigation of industry 4.0 in manufacturing: Theoretical operationalisation framework. Prod. Plan.Control 2018, 29, 633-644. [CrossRef]

43. Miśkiewicz, R.; Wolniak, R. Practical Application of the Industry 4.0 Concept in a Steel Company. Sustainability 2020, $12,5776$. [CrossRef]

44. Lu, Y. Industry 4.0: A survey on technologies, applications and open research issues. J. Ind. Inf. Integr. 2017, 6, 1-10. [CrossRef]

45. Birkel, H.; Veile, J.W.; Müller, J.M.; Hartmann, E.; Voigt, K.-I. Development of a Risk Framework for Industry 4.0 in the Context of Sustainability for Established Manufacturers. Sustainability 2019, 11, 384. [CrossRef]

46. Pilloni, V. How Data Will Transform Industrial Processes: Crowdsensing, Crowdsourcing and Big Data as Pillars of Industry 4.0. Future Internet 2018, 10, 24. [CrossRef]

47. Santos, K.; Loures, E.; Piechnicki, F.; Canciglieri, O. Opportunities Assessment of Product Development Process in Industry 4.0 Procedia Manuf. 2017, 11, 1358-1365. [CrossRef]

48. Strozzi, F.; Colicchia, C.; Creazza, A.; Noè, C. Literature review on the 'Smart Factory' concept using bibliometric tools. Int. J. Prod. Res. 2017, 55, 6572-6591. [CrossRef]

49. Grabowska, S.; Saniuk, S. Business Models in the Industry 4.0 Environment-Results of Web of Science Bibliometric Analysis. J. Open Innov. Technol. Mark. Complex. 2022, 8, 19. [CrossRef]

50. Berger, R. Industry 4.0-The New Industrial Revolution-How Europe Will Succeed; Roland Berger Strategy Consultants: Munich, Germany, 2014

51. Grzybowska, K.; Awasthi, A. Literature review on sustainable logistics and sustainable production for Industry 4.0. In Sustainable Logistics and Production in Industry 4.0 New Opportunities and Challenges; Grzybowska, K., Awasthi, A., Sawhney, R., Eds.; Springer: New York, NY, USA, 2020; pp. 1-19.

52. García-Muiña, F.E.; Medina-Salgado, M.S.; Ferrari, A.M.; Cucchi, M. Sustainability transition in industry 4.0 and smart manufacturing with the triple-layered business model canvas. Sustainability 2020, 12, 2364. [CrossRef]

53. Gabriel, M.; Pessl, E. Industry 4.0 and sustainability impacts: Critical discussion of sustainability aspects with a special focus on future of work and ecological consequences. Ann. Fac. Eng. Hunedoara 2016, 14, 131.

54. Rojko, A. Industry 4.0 concept: Background and overview. Int. J. Interact. Mob. Technol. 2017, 11, 77-90. [CrossRef] 
55. Zoubek, M.; Poor, P.; Broum, T.; Basl, J.; Simon, M. Industry 4.0 Maturity Model Assessing Environmental Attributes of Manu-facturing Company. Appl. Sci. 2021, 11, 5151. [CrossRef]

56. Zhou, F.; Ji, Y.; Jiao, R. Affective and cognitive design for mass personalization: Status and prospect. J. Intell. Man-Ufacturing 2013, 24, 1047-1069. [CrossRef]

57. Młody, M. Product personalization and Industry 4.0-Assessment of the rightness of the implementation of modern technologies in the manufacturing industry from the consumers' perspective. Ekon. I Organ. Przedsiębiorstwa 2018, 2, 62-72.

58. Arnold, C.; Veile, J.; Voigt, K.I. What drives industry 4.0 adoption? An examination of technological, organizational, and environmental determinants. In Proceedings of the International Association for Management of Technology (IAMOT) Conference, Birmingham, UK, 22-26 April 2018; pp. 22-26.

59. Broo, D.G.; Kaynak, O.; Sait, S.M. Rethinking Engineering Education at the Age of Industry 5.0. J. Ind. Inf. Integr. $2021,25,100311$. [CrossRef]

60. Breque, M.; De Nul, L.; Petridis, A. Industry 5.0. Towards a Sustainable, Human-Centric and Resilient European Industry Available online: https:/ / op.europa.eu/en/publication-detail/-/publication/468a892a-5097-11eb-b59f-01aa75ed71a1/ (accessed on 15 December 2021).

61. Özdemir, V.; Hekim, N. Birth of industry 5.0: Making sense of big data with artificial intelligence, the internet of things and next-generation technology policy. Omics J. Integr. Biol. 2018, 22, 65-76. [CrossRef]

62. Demir, K.A.; Döven, G.; Sezen, B. Industry 5.0 and human-robot co-working. Procedia Comput. Sci. 2019, 158, 688-695. [CrossRef]

63. Madsen, D.Ø.; Berg, T. An Exploratory Bibliometric Analysis of the Birth and Emergence of Industry 5.0. Appl. Syst. Innov. 2021, 4, 87. [CrossRef]

64. Rada, M. Industry 5.0 Definition. 2018. Available online: https://michael-rada.medium.com/industry-5-0-definition-6a2f992 2dc48 (accessed on 15 December 2021).

65. Rada, M. Industry 5.0-From Virtual to Physical. 2015. Available online: https://www.linkedin.com/pulse/industry-50-fromvirtual-physical-michael-rada (accessed on 15 December 2021).

66. Nahavandi, S. Industry 5.0—A human-centric solution. Sustainability 2019, 11, 4371. [CrossRef]

67. Aslam, F.; Aimin, W.; Li, M.; Rehman, K. Innovation in the era of IoT and industry 5.0: Absolute innovation management (AIM) framework. Information 2020, 11, 124. [CrossRef]

68. Haleem, A.; Javaid, M. Industry 5.0 and its expected applications in medical field. Curr. Med. Res. Pr. 2019, 9, 167-169. [CrossRef]

69. Di Nardo, M.; Yu, H. Special issue "Industry 5.0: The prelude to the sixth industrial revolution". Appl. Syst. Innov. 2021, 4, 45. [CrossRef]

70. Vollmer, M. What is Industry 5.0? 2018. Available online: https://medium.com/@marcellvollmer/what-is-industry-5-0-a36304 1a6f0a (accessed on 15 December 2021).

71. Sachsenmeier, P. Industry 5.0-The relevance and implications of bionics and synthetic biology. Engineering 2016, 2, 225-229. [CrossRef]

72. Nourmohammadi, A.; Fathi, M.; Ng, A.H. Balancing and scheduling assembly lines with human-robot collaboration tasks. Comput. Oper. Res. 2021, 140, 105674. [CrossRef]

73. Saniuk, S.; Grabowska, S. The Concept of Cyber-Physical Networks of Small and Medium Enterprises under Personalized Manufacturing. Energies 2021, 14, 5273. [CrossRef]

74. Humayun, M. Industrial Rewvolution 5.0 and the Role of Cutting Edge Technologies. Int. J. Adv. Comput. Sci. Appl. 2021, 12, 12.

75. Østergaard, E.H. Welcome to Industry 5.0. Retrieved Febr. 2018, 5, 2020. [CrossRef]

76. Martynov, V.V.; Shavaleeva, D.N.; Zaytseva, A.A. Information Technology as the Basis for Transformation into a Digital Society and Industry 5.0. In Proceedings of the 2019 International Conference Quality Management, Transport and Information Security, Information Technologies, Sochi, Russia, 23-27 September 2019; pp. 539-543.

77. ElFar, O.A.; Chang, C.K.; Leong, H.Y.; Peter, A.P.; Chew, K.W.; Show, P.L. Prospects of Industry 5.0 in algae: Customization of production and new advance technology for clean bioenergy generation. Energy Convers. Manag. 2021, 10, 100048. [CrossRef]

78. Gorodetsky, V.; Larukchin, V.; Skobelev, P. Conceptual model of digital platform for enterprises of industry 5.0. In International Symposium on Intelligent and Distributed Computing; Springer: Cham, Switzerland, 2019.

79. Doyle-Kent, M.; Kopacek, P. Industry 5.0: Is the manufacturing industry on the cusp of a new revolution? In Proceedings of the International Symposium for Production Research 2019; Springer: Cham, Switzerland, 2019.

80. Elim, H.I.; Zhai, G. Control system of multitasking interactions between society 5.0 and industry 5.0: A conceptual introduction \& its applications. J. Phys. Conf. Ser. 2020, 1463, 012035.

81. Demir, K.; Cicibas, H. Industry 5.0 and a critique of industry 4.0. In Proceedings of the 4th International Management Information Systems Conference, Istanbul, Turkey, 17-20 October 2017; pp. 17-20.

82. Fonda, E.; Meneghetti, A. The Human-Centric SMED. Sustainability 2022, 14, 514. [CrossRef]

83. John, K.K.; Adarsh, S.N.; Pattali, V. Workers to super workers: A brief discussion on important technologies for industry 5.0 manufacturing systems. In AIP Conference Proceedings; AIP Publishing LLC: Melville, NY, USA, 2020; Volume 2311, p. 070025.

84. Yordanova, K. The Curious Case of Industry 5.0. Available online: https://www.law.kuleuven.be/citip/blog/the-curious-caseof-industry-5-0/ (accessed on 15 December 2021).

85. Grabowska, S. Model Biznesu 4.0. Architektura, Tworzenie Wartości, Ocena Konkurencyjności i Efektywności; TNOIK: Toruń, Poland, 2021. 
86. Castells, M. The Internet Galaxy: Reflections on the Internet, Business, and Society; Oxford University Press: Oxford, UK, 2002.

87. Bauman, R. A World of Others' Words: Cross-Cultural Perspectives on Intertextuality; John Wiley \& Sons: Hoboken, NJ, USA, 2008.

88. Janowska, A.A.; Skrzek-Lubasińska, M. Kompetencje przyszłości w warunkach ekspansji gospodarki 4.0. Studia Ekon. 2019, 379, 57-71.

89. Wolter, M.; Monning, A.; Hummel, M.; Weber, E.; Zika, E.; Helmirch, R.; Maier, T.; Neuber-Polk, C. Economy 4.0 and Its Labour Market and Economic Impacts 2016. Available online: http://doku.iab.de/forschungsbericht/2016/fb1316_en.pdf (accessed on 15 December 2021).

90. Cellary, W. Non-technical Challenges of Industry 4.0. In Collaborative Networks and Digital Transformation; Springer: Berlin/Heidelberg, Germany, 2019; pp. 3-10.

91. Azevedo, A. Collaborative Transformation Systems-Path to Address the Challenges around the Competitiveness of Mature Countries; Camarinha-Matos, L.M., Afsarmanesh, H., Rezgui, Y., Eds.; Springer: Cham, Switzerland, 2018; Volume 534, pp. 21-32. [CrossRef]

92. Keidanren, N. Toward Realization of the New Economy and Society. Reform of the Economy and Society by the Deepening of "Society 5.0"; Japan Business Federation: Tokyo, Japan, 2016.

93. Deguchi, A.; Hirai, C.; Matsuoka, H.; Nakano, T.; Oshima, K.; Tai, M.; Tani, S. What is society 5.0. Society 2020, 5, 1-23.

94. Fukuyama, M. Society 5.0: Aiming for a new human-centered society. Jpn. Spotlight 2018, 1,47-50.

95. Salgues, B. Society 5.0: Industry of the Future, Technologies, Methods and Tools; John Wiley \& Sons: Hoboken, NJ, USA, 2018.

96. Japan Growth Strategy 2017. Available online: https://www.mofa.go.jp/files/000272312.pdf (accessed on 15 December 2021).

97. Japan Revitalization Strategy 2015. Available online: https://www.kantei.go.jp/jp/singi/keizaisaisei/pdf/souron_gaiyouen.pdf (accessed on 15 December 2021).

98. Palazzeschi, L.; Bucci, O.; Di Fabio, A. Re-thinking innovation in organizations in the industry 4.0 scenario: New challenges in a primary prevention perspective. Front. Psychol. 2018, 9, 30. [CrossRef] [PubMed]

99. Lee, J.; Kao, H.-A.; Yang, S. Service Innovation and Smart Analytics for Industry 4.0 and Big Data Environment. Procedia CIRP 2014, 16, 3-8. [CrossRef]

100. Shiroishi, Y.; Uchiyama, K.; Suzuki, N. Better actions for society 5.0: Using AI for evidencebased policy making that keeps humans in the loop. Computer 2019, 52, 73-78. [CrossRef]

101. Shiroishi, Y.; Uchiyama, K.; Suzuki, N. Society 5.0: For human security and well-being. Computer 2018, 51, 91-95. [CrossRef]

102. Nakanishi, H. Modern Society Has Reached Its Limits_ “Society 5.0" Will Liberate Us; World Economic Forum: Davos, Switzerland, 2019.

103. Takeuchi, Y.; Morishita, H.; Sato, Y.; Hamaguchi, S.; Sakamoto, N.; Tokue, H.; Sato, M. Guidelines for the use of NBCA in vascular embolization devised by the Committee of Practice Guidelines of the Japanese Society of Interventional Radiology (CGJSIR). Jpn. J. Radiol. 2014, 32, 500-517. [CrossRef]

104. De Man, J.; Strandhagen, J. An Industry 4.0 research agenda for sustainable business models. Procedia CIRP 2017, 63, 721-726. [CrossRef] 